\title{
The Ability of Secretory Leukocyte Protease Inhibitor to Inhibit Apoptosis in Monocytes Is Independent of Its Antiprotease Activity
}

\author{
Niamh McGarry, ${ }^{1}$ Catherine M. Greene, ${ }^{1}$ Noel G. McElvaney, ${ }^{1}$ \\ Sinéad Weldon, ${ }^{2}$ and Clifford C. Taggart ${ }^{2}$ \\ ${ }^{1}$ Respiratory Research Division, Department of Medicine, Education and Research Centre, Royal College of Surgeons in Ireland, \\ Dublin 9, Ireland \\ ${ }^{2}$ Centre for Infection and Immunity, School of Medicine, Dentistry and Biomedical Sciences, Health Sciences Building, \\ Queen's University Belfast, 97 Lisburn Road, Belfast BT9 7AE, UK
}

Correspondence should be addressed to Sinéad Weldon; s.weldon@qub.ac.uk

Received 17 March 2015; Revised 20 June 2015; Accepted 23 June 2015

Academic Editor: Selvan Senthamil

Copyright (C) 2015 Niamh McGarry et al. This is an open access article distributed under the Creative Commons Attribution License, which permits unrestricted use, distribution, and reproduction in any medium, provided the original work is properly cited.

Secretory Leukocyte Protease Inhibitor (SLPI) is a serine protease inhibitor produced by epithelial and myeloid cells with antiinflammatory properties. Research has shown that SLPI exerts its anti-inflammatory activity by directly binding to NF- $\kappa$ B DNA binding sites and, in so doing, prevents binding and subsequent transcription of proinflammatory gene expression. In the current study, we demonstrate that SLPI can inhibit TNF- $\alpha$-induced apoptosis in U937 cells and peripheral blood monocytes. Specifically, SLPI inhibits TNF- $\alpha$-induced caspase-3 activation and DNA degradation associated with apoptosis. We go on to show that this ability of SLPI to inhibit apoptosis is not dependent on its antiprotease activity as antiprotease deficient variants of SLPI can also inhibit TNF- $\alpha$-induced apoptosis. This reduction in monocyte apoptosis may preserve monocyte function during inflammation resolution and promote infection clearance at mucosal sites.

\section{Introduction}

Secretory Leukocyte Protease Inhibitor (SLPI) is a small molecular weight protein with multifunctional properties including antiprotease, antibacterial, antiviral, and antiinflammatory effects [1]. The mature SLPI protein is $11.7 \mathrm{kDa}$ in length and consists of 107 amino acids which are arranged in two domains of similar folding, giving SLPI a boomerang shape $[2,3]$. Each domain is homologous to the whey acidic protein (WAP) four-disulphide core (WFDC) domain [4]. SLPI is constitutively expressed in the majority of mucosal secretions including nasal, bronchial, salivary, tear, cervical, and seminal secretions [5-8]. SLPI is produced and secreted by a number of different cell types including neutrophils and macrophages and by the epithelial cells that line mucosal surfaces. The physiological concentration of SLPI in saliva ranges from 4 to $24 \mu \mathrm{g} / \mathrm{mL}$ [9]. Lung epithelial lining fluid levels of SLPI can be as high as $10 \mu \mathrm{g} / \mathrm{mL}$, although SLPI concentrations have been found to be higher in upper respiratory airways than in lower airways $[1,9,10]$. The production of SLPI in such defense sensitive locations where protection against pathogen is pivotal reinforces the important role SLPI plays in innate immune defense.

SLPI inhibits a wide variety of proteases including neutrophil elastase (NE), cathepsin G, trypsin, chymotrypsin, chymase, and tryptase [11]. In addition, research suggests that SLPI has antimicrobial effects and is capable of inhibiting both Gram positive (Staphylococcus aureus) and Gram negative (Escherichia coli) bacterial growth $[12,13]$ as well as inhibiting HIV viral replication in monocytic cells $[14,15]$. In relation to immunomodulation, Jin et al. have shown that SLPI expression in macrophages is induced by lipopolysaccharide (LPS) and suppressed by IFN- $\gamma$ [16]. SLPI inhibited LPS-induced NF- $\kappa$ B activation in macrophages thereby 
decreasing production of TNF- $\alpha$ and IL-8 [17]. Ding et al. showed that SLPI can interfere with uptake of LPS into macrophages [18]. SLPI has been demonstrated to prevent the degradation of key regulatory proteins IRAK, I $\kappa \mathrm{B} \alpha$, and $\mathrm{I} \kappa \mathrm{B} \beta$ in response to LPS and lipoteichoic acid [19-21]. In addition, SLPI exerts a direct effect by entering the nucleus and competing with the p65 subunit of NF- $\kappa \mathrm{B}$ for binding to its promoter regions in target genes. Therefore, LPSinduced binding of $\mathrm{p} 65$ to the NF- $\kappa \mathrm{B}$ consensus-binding sites in the promoter regions of these genes is prevented and production of proinflammatory factors such as TNF- $\alpha$ and IL- 8 is decreased [17].

To date, there has been very little research in the area of SLPI's ability to inhibit apoptosis. One study has shown that SLPI can inhibit neutrophil apoptosis [22] but the mechanism for this effect is unknown. In this study, we demonstrate that SLPI can inhibit apoptosis in monocytic cells in a way that does not depend on the protease inhibition effect of SLPI.

\section{Materials and Methods}

2.1. Materials. The SLPI mutants Lys72SLPI and Gly72SLPI [23] were provided by Amgen (Thousand Oaks, Ca, USA).

2.2. Cell Culture. Ethical approval for use of peripheral blood monocytes (PBMs) from whole blood was given by Beaumont Hospital Ethics Committee. Human myelomonocytic U937 cells were purchased from the American Type Culture Collection (Manassas, USA). PBMs and U937s were routinely cultured in RPMI 1640 medium supplemented with $10 \%$ heat-inactivated foetal calf serum (Gibco, Life Technologies), $2 \mathrm{mM}$ L-glutamine, and $1 \%(\mathrm{v} / \mathrm{v})$ penicillin/streptomycin (PAA laboratories $\mathrm{GmbH}$, Austria). Cells for experiments were seeded at $5 \times 10^{5} / \mathrm{mL}$ and were preincubated with SLPI, oxidised SLPI, or SLPI mutants for $1 \mathrm{hr}$ followed by incubation with TNF- $\alpha$ (R\&D Systems; $10 \mathrm{ng} / \mathrm{mL})$.

2.3. Caspase Activity Assays. Caspase- 3 and caspase-7 activity was determined using the fluorogenic substrate Ac-AspGlu-Val-Asp-7-amino-4-methylcoumarin (DEVD-AMC; Enzo Life Sciences LTD, Exeter, UK). Briefly, cells were centrifuged at $1000 \times \mathrm{g}$ for 5 minutes at $4^{\circ} \mathrm{C}$ and lysed in lysis buffer ( $50 \mathrm{mM}$ Tris $\mathrm{pH}$ 7.5, $150 \mathrm{mM} \mathrm{NaCl}, 5 \mathrm{mM}$ EDTA, and $0.2 \%$ Nonidet P-40). The cells were then centrifuged at $17,000 \times \mathrm{g}$ or $10 \mathrm{~min}$ at $4^{\circ} \mathrm{C}$. The reaction buffer was $10 \mathrm{mM}$ HEPES (pH7.5), $50 \mathrm{mM} \mathrm{NaCl}, 5 \mathrm{mM} \mathrm{MgCl}_{2}, 2.5 \mathrm{mM}$ DTT, and $1 \mathrm{mM}$ EDTA. Samples were incubated with substrate (50 $\mu \mathrm{M})$ and fluorescence (substrate turnover) was determined by excitation at $360 \mathrm{~nm}$ and emission at $460 \mathrm{~nm}$ in a 96 -well microplate reader. The rate of substrate hydrolysis was monitored at $37^{\circ} \mathrm{C}$ and results were expressed as the change $(\Delta)$ in relative fluorescence units $(\triangle \mathrm{RFU})$ over a $60 \mathrm{~min}$ period.

2.4. Western Blotting. Whole cell extracts were prepared for Western blotting analysis by lysing cell lines and PBECs in RIPA buffer (50 mm Tris- $\mathrm{HCl}, \mathrm{pH} 7.5,150 \mathrm{~mm} \mathrm{NaCl}, 1 \%$ Nonidet P-40, 0.25\% sodium deoxycholate, $1 \mathrm{~mm}$ EDTA, and $1 \%$ Triton X-100) supplemented with PMSF, aprotinin, and sodium orthovanadate. Total protein concentrations were determined using the BCA method (Pierce BCA Assay, Fisher Scientific UK, Leicestershire). Denatured samples were separated by electrophoresis on $12 \%$ SDS-polyacrylamide gels, transferred to nitrocellulose membrane, and probed using rabbit anti-caspase-3, rabbit anti-caspase-7 (Cell Signalling, $1: 1000$ ), or rabbit anti-GAPDH (Santa Cruz Biotechnology Inc., $1: 1000)$. Binding was detected using the appropriate horseradish peroxidase-conjugated secondary antibodies (Fisher Scientific UK), visualized by chemiluminescence (GE Healthcare UK, Buckinghamshire), and analysed using the Syngene G:Box and GeneSnap software (SynGene UK, Cambridge).

2.5. Cell Death ELISA. The cell death ELISA kit (Roche) was used to quantify apoptosis levels. The ELISA was carried out according to the manufacturer's instructions.

2.6. Oxidation of SLPI. Oxidation of SLPI was carried out as described previously [19].

2.7. Statistical Analysis. All data were analysed using GraphPad Prism 5.0 (GraphPad Software Inc., San Diego, CA) and are reported as mean \pm SEM. Results are representative of at least $n=3$ unless otherwise indicated. Means were compared by unpaired $t$-test or one-way analysis of variance (ANOVA) as appropriate. $p<0.05$ was accepted to indicate statistical significance.

\section{Results}

3.1. SLPI Inhibits TNF- $\alpha$-Induced Caspase-3 and Caspase-7 Activity in Monocytic Cells. As effector caspases are responsible for most of the physiological changes that occur in apoptosis, SLPI's effect on effector caspase- 3 and caspase-7 activity was initially investigated using the specific substrate DEVD-AMC (Figure 1(a)). U937 monocytes treated with TNF- $\alpha$ showed an increase in DEVD-AMC activity compared to control cells, indicating upregulation in caspase- 3 and caspase- 7 activity in response to TNF- $\alpha$ stimulation. In comparison to cells treated with TNF- $\alpha$ alone, a significant decrease in caspase- 3 and caspase-7 activity was observed in U937 monocytes pretreated with SLPI. This result suggests that SLPI is having an antiapoptotic effect in TNF- $\alpha$ treated monocytes.

\subsection{SLPI Inhibits TNF- $\alpha$-Induced Cell Death in Monocytic} Cells. SLPI's effect on TNF- $\alpha$-induced apoptosis was investigated further using a cell death ELISA. The presence of monoand oligonucleosomes in the cytoplasm of apoptotic cells is due to DNA degradation and occurs several hours before the plasma membrane breakdown. This assay detects the amount of mono- and oligonucleosomes in the cytoplasmic fraction of cell lysates permitting detection of apoptosis. U937 monocytes treated with TNF- $\alpha$ showed an increase in the amount of apoptosis as expected which was significantly decreased in the presence of SLPI (Figure 1(b)). This result is consistent 


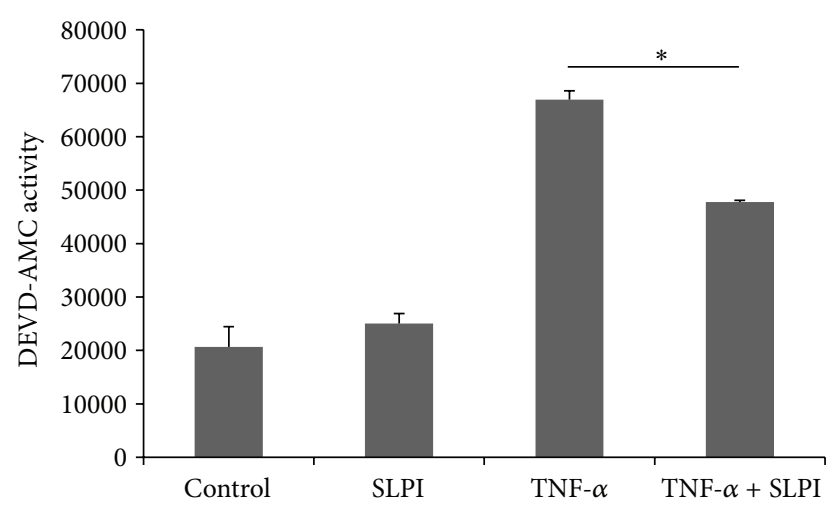

(a)

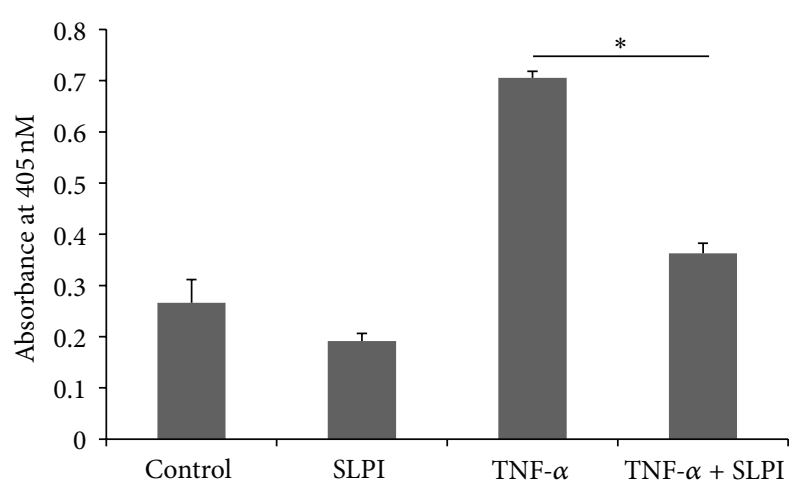

(b)

FIGURE 1: Effect of SLPI on TNF- $\alpha$-induced caspase- 3 and caspase-7 activity and cell death. U937 monocytic cells were pretreated for 1 hr with SLPI $(10 \mu \mathrm{g} / \mathrm{mL})$ and stimulated with TNF- $\alpha(10 \mathrm{ng} / \mathrm{mL})$ for $4 \mathrm{hr}$. (a) Activity of the effector caspases, caspase-3 and caspase-7, was measured using the fluorogenic substrate DEVD-AMC. Results are representative of $n=6$. (b) The amount of apoptosis occurring in cells was measured by ELISA. Results are representative of $n=6$ experiments. $*$ indicates $p<0.05$.

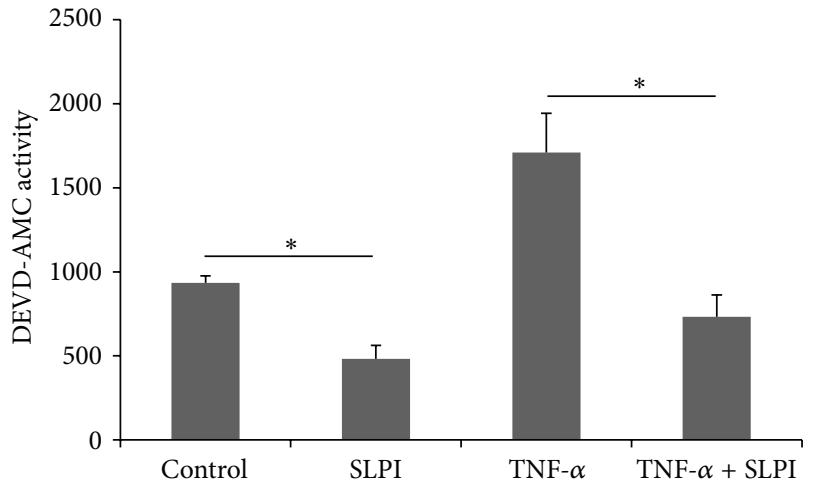

FIGURE 2: Effect of SLPI on TNF- $\alpha$-induced caspase-3 and caspase-7 activity in peripheral blood monocytes. Peripheral blood monocytes were isolated and pretreated for $1 \mathrm{hr}$ with SLPI $(10 \mu \mathrm{g} / \mathrm{mL})$ and then incubated with TNF- $\alpha(10 \mathrm{ng} / \mathrm{mL})$ for $4 \mathrm{hr}$. Activity of the effector caspases, caspase- 3 and caspase-7, was measured using the fluorogenic substrate DEVD-AMC. Results are representative of $n=$ 6. $*$ indicates $p<0.05$.

with previous findings that SLPI has an antiapoptotic effect on TNF- $\alpha$ treated monocytes.

3.3. SLPI Inhibits TNF- $\alpha$-Induced Caspase Activation in Peripheral Blood Monocytes. To ensure that the results found in the U937 cell line were physiologically representative of monocytes, peripheral blood monocytes (PBMs) were isolated and treated with TNF- $\alpha$ alone and in the presence of SLPI. PBMs treated with SLPI exhibited a significant reduction in basal and TNF- $\alpha$-induced caspase activity (Figure 2). This suggested that results obtained with the U937 cells were physiologically relevant.
3.4. The Role of SLPI's Antiprotease Activity in the Inhibition of TNF- $\alpha$-Induced Apoptosis. The effect of antiproteasedeficient variants of SLPI (Lys72SLPI, Gly72SLPI, and oxidised SLPI) $[19,23]$ on the inhibition of apoptosis was investigated. Lys72SLPI, Gly72SLPI, and oxidized SLPI retained the ability to inhibit TNF- $\alpha$-induced apoptosis as evidenced by caspase- 3 and caspase-7 activity assays (Figure 3(a)) and cell death ELISA results (Figure 3(b)). These findings suggest that the antiapoptotic ability of SLPI is independent of its antiprotease activity.

3.5. Investigation into SLPI's Mechanism of Apoptosis Inhibition. U937 cell lysates were prepared from cells treated with TNF- $\alpha$ alone and in the presence of SLPI and levels of active caspase -3 and caspase- 7 investigated by Western blotting. Despite the fact that there was a decrease in caspase- 3 and caspase-7 activity (Figure 1(a)), active forms of both caspases were found in cells treated with TNF- $\alpha$ in the presence of SLPI as shown in Figure 4. However, the levels of active caspase- 3 appear reduced in cells treated with TNF- $\alpha$ and SLPI compared to cells stimulated with TNF- $\alpha$ alone. To address the possibility that SLPI may directly inhibit caspase3 activity, recombinant caspase- 3 was pretreated with a molar excess of SLPI prior to the addition of DEVD-AMC. As illustrated in Figure 5, no inhibition of active caspase- 3 was detected.

\section{Discussion}

SLPI has been shown to inhibit LPS-induced NF- $\kappa$ B activation by displacing or inhibiting NF- $\kappa \mathrm{B}$ binding to its promoter regions in target genes [17]. As well as inducing a host of proinflammatory cytokines, NF- $\kappa \mathrm{B}$ activation also leads to the induction of prosurvival factors, which combine to inhibit apoptosis. Therefore, the effect of SLPI on TNF- $\alpha$-induced apoptosis was investigated to see if SLPI 


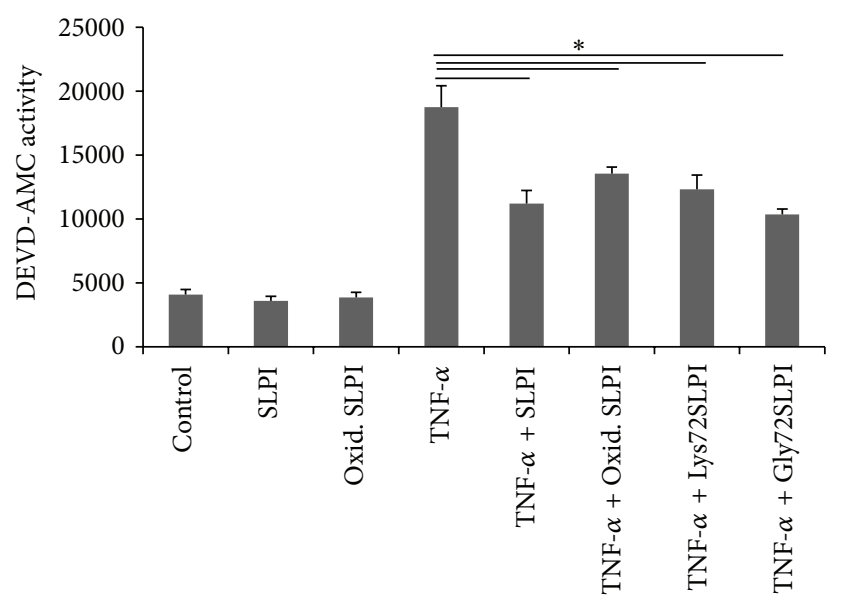

(a)

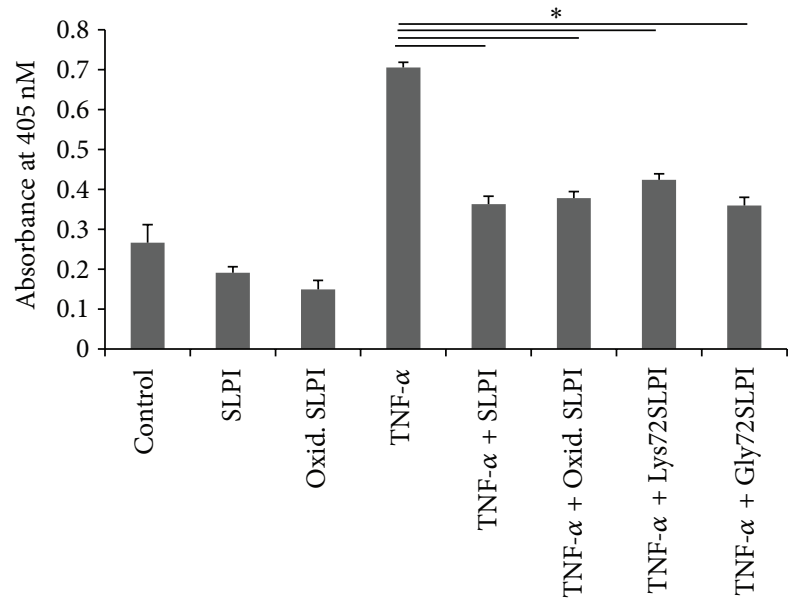

(b)

FIGURE 3: Effect of SLPI and oxidised SLPI on apoptosis in monocytic cells. U937 cells were pretreated with SLPI (10 $\mu \mathrm{g} / \mathrm{mL})$ or oxidised SLPI $(10 \mu \mathrm{g} / \mathrm{mL})$ and stimulated with TNF- $\alpha(10 \mathrm{ng} / \mathrm{mL})$ for $4 \mathrm{hr}$. (a) Activity of the effector caspases, caspase-3 and caspase-7, was measured using the fluorogenic substrate DEVD-AMC. (b) The amount of apoptosis occurring in cells was assessed by ELISA (Roche). Results are representative of $n=3$. * indicates $p<0.05$.

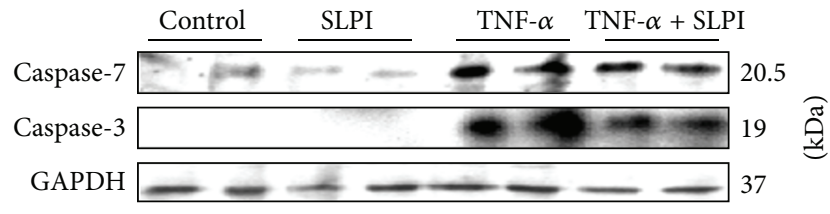

FIGURE 4: Effect of SLPI on active caspase-3 and caspase-7 protein levels. U937 cells were pretreated with SLPI $(10 \mu \mathrm{g} / \mathrm{mL})$ and stimulated with TNF- $\alpha(10 \mathrm{ng} / \mathrm{mL})$ for $4 \mathrm{hr}$. RIPA extracts were electrophoresed on 10-15\% SDS-PAGE gels and analysed by Western blotting using anti-caspase- 3 and anti-caspase- 7 antibodies. The blots were tripped and reprobed for GAPDH to control for protein loading. Results are representative of $n=3$.

was capable of inhibiting NF- $\kappa \mathrm{B}$ antiapoptotic effects. We induced apoptosis using TNF- $\alpha$ which has previously been shown to have proapoptotic effects in monocytic cells [24]. Surprisingly, SLPI was shown to downregulate caspase- 3 and caspase-7 activity and inhibit TNF- $\alpha$-induced apoptosis in monocytes. This effect was further investigated using the cell death ELISA which confirmed that SLPI inhibited TNF- $\alpha$ induced cell death.

Both NE and cathepsin G have previously been shown to play a role in apoptosis $[25,26]$. Therefore, we hypothesised that, as a serine protease inhibitor, SLPI inhibits apoptosis via NE or cathepsin G inhibition. To test this, we evaluated antiprotease deficient variants of SLPI (Lys72SLPI, Gly72SLPI, and oxidised SLPI) [19, 23]. The antiprotease inactive forms of SLPI retained the ability of inhibiting TNF- $\alpha$ induced apoptosis suggesting that SLPI's antiapoptotic effects were not mediated by its antiprotease activity. In relation to SLPI's anti-inflammatory activity, the literature is conflicting regarding the role that SLPI's antiprotease function plays in mediating these effects $[27,28]$.

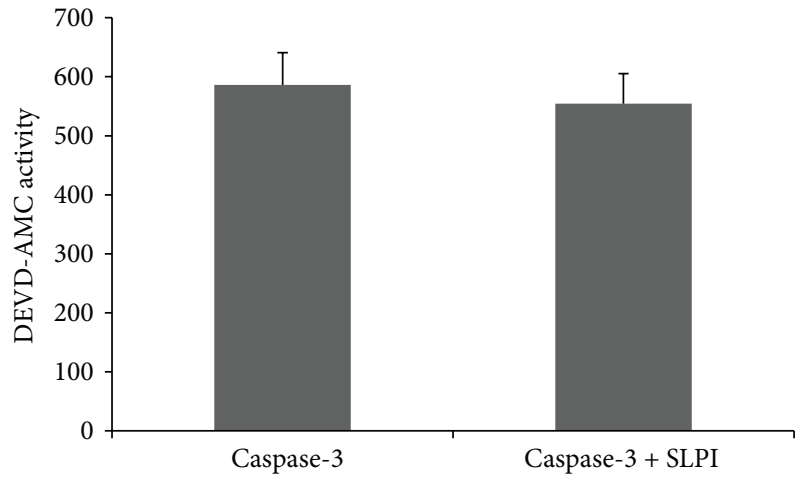

FIGURE 5: Effect of SLPI on recombinant caspase-3 activity. SLPI (100 ng) was pretreated for $1 \mathrm{hr}$ with recombinant human caspase3 (10 ng). Caspase-3 activity was measured using the fluorogenic substrate DEVD-AMC. Results are representative of $n=5$.

In a bid to understand how SLPI may mediate its antiapoptotic activity, the effect of SLPI on other components of the apoptotic pathway was then investigated. Similar to SLPI, PR39 is a small, highly cationic, and antimicrobial peptide which can also enter cells and inhibit apoptosis. PR39 achieves this through the upregulation of the antiapoptotic protein IAP-2 [29]. IAP-2 and other IAP family members inhibit caspase- 3 and caspase-7 activity. We therefore hypothesised that SLPI could act in a similar manner to PR39 by upregulating IAP family members which could inhibit caspase- 3 and caspase- 7 directly. We looked at the effect of SLPI on IAP-1, IAP-2, survivin, and XIAP protein levels but found that SLPI did not upregulate any of these factors (data not shown). In addition, SLPI was unable to directly inhibit recombinant caspase-3 activity. However, as the levels of active caspase- 3 appear lower in cells treated with TNF- $\alpha$ and SLPI compared to cells stimulated with TNF- $\alpha$ alone, it is 
possible that at least part of SLPI's antiapoptotic mechanism may involve inhibition of the generation of active caspase- 3 from its inactive zymogen perhaps via inhibition of upstream initiator caspases such as caspase-8. Further work is required to elucidate the exact mechanism by which SLPI exerts its antiapoptotic effects in response to TNF- $\alpha$. Previous work has reported the ability of SLPI to limit TNF- $\alpha$-induced hydrogen peroxide production by human neutrophils $[27,30]$; therefore, it is also possible that SLPI may be able to interfere with more upstream TNF- $\alpha$ signalling intermediates.

From a physiological standpoint, SLPI's antiapoptotic effect in monocytes may be important for optimising the removal of dying cells and bacteria as part of the inflammation resolution process and the fight against infection. Conditions such as emphysema and cystic fibrosis, characterised where SLPI levels are altered by degradation $[10,31]$ in the lung, are dominated by a chronic inflammatory response, excessive apoptosis, and infection. Therefore, SLPI's role in controlling this process on the respiratory tract may be an important homeostatic mechanism in maintaining sufficient monocyte numbers for infection and inflammation resolution. More work is needed to determine the mechanism by which SLPI alters apoptotic pathways.

\section{Conflict of Interests}

The authors declare that there is no conflict of interests regarding the publication of this paper.

\section{Acknowledgments}

The authors wish to acknowledge funding from Science Foundation Ireland (04/BR/B0640) C. C. Taggart and the Alpha One Foundation C. C. Taggart.

\section{References}

[1] S. Weldon, N. McGarry, C. C. Taggart, and N. G. McElvaney, "The role of secretory leucoprotease inhibitor in the resolution of inflammatory responses," Biochemical Society Transactions, vol. 35, no. 2, pp. 273-276, 2007.

[2] M. G. Grütter, G. Fendrich, R. Huber, and W. Bode, “The 2.5 A X-ray crystal structure of the acid-stable proteinase inhibitor from human mucous secretions analysed in its complex with bovine alpha-chymotrypsin," The EMBO Journal, vol. 7, no. 2, pp. 345-351, 1988.

[3] S. Ranganathan, K. J. Simpson, D. C. Shaw, and K. R. Nicholas, "The whey acidic protein family: a new signature motif and three-dimensional structure by comparative modeling," Journal of Molecular Graphics and Modelling, vol. 17, no. 2, pp. 106-113, 1999.

[4] A. Clauss, H. Lilja, and Å. Lundwall, "A locus on human chromosome 20 contains several genes expressing protease inhibitor domains with homology to whey acidic protein," Biochemical Journal, vol. 368, no. 1, pp. 233-242, 2002.

[5] B. Appelhans, B. Ender, G. Sachse, T. Nikiforov, H. Appelhans, and W. Ebert, "Secretion of antileucoprotease from a human lung tumor cell line," FEBS Letters, vol. 224, no. 1, pp. 14-18, 1987.
[6] C. Franken, C. J. L. M. Meijer, and J. H. Dijkman, "Tissue distribution of antileukoprotease and lysozyme in humans," Journal of Histochemistry and Cytochemistry, vol. 37, no. 4, pp. 493498, 1989.

[7] R. Heinzel, H. Appelhans, G. Gassen et al., "Molecular cloning and expression of cDNA for human antileukoprotease from cervix uterus," European Journal of Biochemistry, vol. 160, no. 1, pp. 61-67, 1986.

[8] C. H. Lee, Y. Igarashi, R. J. Hohman, H. Kaulbach, M. V. White, and M. A. Kaliner, "Distribution of secretory leukoprotease inhibitor in the human nasal airway," American Review of Respiratory Disease, vol. 147, no. 3, pp. 710-716, 1993.

[9] C. Vogelmeier, R. C. Hubbard, G. A. Fells et al., "Anti-neutrophil elastase defense of the normal human respiratory epithelial surface provided by the secretory leukoprotease inhibitor," Journal of Clinical Investigation, vol. 87, no. 2, pp. 482-488, 1991.

[10] C. C. Taggart, G. J. Lowe, C. M. Greene et al., "Cathepsin B, L, and S cleave and inactivate secretory leucoprotease inhibitor," The Journal of Biological Chemistry, vol. 276, no. 36, pp. 3334533352, 2001.

[11] R. C. Thompson and K. Ohlsson, "Isolation, properties, and complete amino acid sequence of human secretory leukocyte protease inhibitor, a potent inhibitor of leukocyte elastase," Proceedings of the National Academy of Sciences of the United States of America, vol. 83, no. 18, pp. 6692-6696, 1986.

[12] O. Wiedow, J. Harder, J. Bartels, V. Streit, and E. Christophers, "Antileukoprotease in human skin: an antibiotic peptide constitutively produced by keratinocytes," Biochemical and Biophysical Research Communications, vol. 248, no. 3, pp. 904909, 1998.

[13] P. S. Hiemstra, R. J. Maassen, J. Stolk, R. Heinzel-Wieland, G. J. Steffens, and J. H. Dijkman, "Antibacterial activity of antileukoprotease," Infection and Immunity, vol. 64, no. 11, pp. 4520-4524, 1996.

[14] T. B. McNeely, M. Dealy, D. J. Dripps, J. M. Orenstein, S. P. Eisenberg, and S. M. Wahl, "Secretory leukocyte protease inhibitor: a human saliva protein exhibiting anti-human immunodeficiency virus 1 activity in vitro," The Journal of Clinical Investigation, vol. 96, no. 1, pp. 456-464, 1995.

[15] T. B. McNeely, D. C. Shugars, M. Rosendahl, C. Tucker, S. P. Eisenberg, and S. M. Wahl, "Inhibition of human immunodeficiency virus type 1 infectivity by secretory leukocyte protease inhibitor occurs prior to viral reverse transcription," Blood, vol. 90, no. 3, pp. 1141-1149, 1997.

[16] F.-Y. Jin, C. Nathan, D. Radzioch, and A. Ding, "Secretory leukocyte protease inhibitor: a macrophage product induced by and antagonistic to bacterial lipopolysaccharide," Cell, vol. 88, no. 3, pp. 417-426, 1997.

[17] C. C. Taggart, S.-A. Cryan, S. Weldon et al., "Secretory leucoprotease inhibitor binds to NF- $\kappa$ B binding sites in monocytes and inhibits p65 binding," The Journal of Experimental Medicine, vol. 202, no. 12, pp. 1659-1668, 2005.

[18] A. Ding, N. Thieblemont, J. Zhu, F. Jin, J. Zhang, and S. Wright, "Secretory leukocyte protease inhibitor interferes with uptake of lipopolysaccharide by macrophages," Infection and Immunity, vol. 67, no. 9, pp. 4485-4489, 1999.

[19] C. C. Taggart, C. M. Greene, N. G. McElvaney, and S. O’Neill, "Secretory leucoprotease inhibitor prevents lipopolysaccharideinduced $\mathrm{I} \kappa \mathrm{B} \alpha$ degradation without affecting phosphorylation or ubiquitination," The Journal of Biological Chemistry, vol. 277, no. 37, pp. 33648-33653, 2002. 
[20] C. M. Greene, N. G. McElvaney, S. J. O’Neill, and C. C. Taggart, "Secretory leucoprotease inhibitor impairs Toll-like receptor 2and 4-mediated responses in monocytic cells," Infection and Immunity, vol. 72, no. 6, pp. 3684-3687, 2004.

[21] A. B. Lentsch, J. A. Jordan, B. J. Czermak et al., "Inhibition of NF-kappaB activation and augmentation of IkappaBbeta by secretory leukocyte protease inhibitor during lung inflammation," American Journal of Pathology, vol. 154, no. 1, pp. 239-247, 1999.

[22] D. Subramaniyam, C. Hollander, U. Westin, J. Erjefält, T. Stevens, and S. Janciauskiene, "Secretory leukocyte protease inhibitor inhibits neutrophil apoptosis," Respirology, vol. 16, no. 2, pp. 300-307, 2011.

[23] S. P. Eisenberg, K. K. Hale, P. Heimdal, and R. C. Thompson, "Location of the protease-inhibitory region of secretory leukocyte protease inhibitor," The Journal of Biological Chemistry, vol. 265, no. 14, pp. 7976-7981, 1990.

[24] N. Karasavvas and Z. Zakeri, "Relationships of apoptotic signaling mediated by ceramide and TNF- $\alpha$ in U937 cells," Cell Death and Differentiation, vol. 6, no. 2, pp. 115-123, 1999.

[25] J. S. Song, C. M. Kang, C. K. Rhee et al., "Effects of elastase inhibitor on the epithelial cell apoptosis in bleomycin-induced pulmonary fibrosis," Experimental Lung Research, vol. 35, no. 10, pp. 817-829, 2009.

[26] A. Sabri, S. G. Alcott, H. Elouardighi et al., "Neutrophil cathepsin $\mathrm{G}$ promotes detachment-induced cardiomyocyte apoptosis via a protease-activated receptor-independent mechanism," The Journal of Biological Chemistry, vol. 278, no. 26, pp. 2394423954, 2003.

[27] J. Yang, J. Zhu, D. Sun, and A. Ding, "Suppression of macrophage responses to bacterial lipopolysaccharide (LPS) by secretory leukocyte protease inhibitor (SLPI) is independent of its anti-protease function," Biochimica et Biophysica Acta: Molecular Cell Research, vol. 1745, no. 3, pp. 310-317, 2005.

[28] M. S. Mulligan, A. B. Lentsch, M. Huber-Lang et al., "Antiinflammatory effects of mutant forms of secretory leukocyte protease inhibitor," The American Journal of Pathology, vol. 156, no. 3, pp. 1033-1039, 2000.

[29] J. Wu, C. Parungo, G. Wu et al., "PR39 inhibits apoptosis in hypoxic endothelial cells: role of inhibitor apoptosis protein-2," Circulation, vol. 109, no. 13, pp. 1660-1667, 2004.

[30] J. Zhu, C. Nathan, W. Jin et al., "Conversion of proepithelin to epithelins: roles of SLPI and elastase in host defense and wound repair," Cell, vol. 111, no. 6, pp. 867-878, 2002.

[31] S. Weldon, P. McNally, N. G. McElvaney et al., "Decreased levels of secretory leucoprotease inhibitor in the Pseudomonasinfected cystic fibrosis lung are due to neutrophil elastase degradation," The Journal of Immunology, vol. 183, no. 12, pp. 81488156, 2009. 


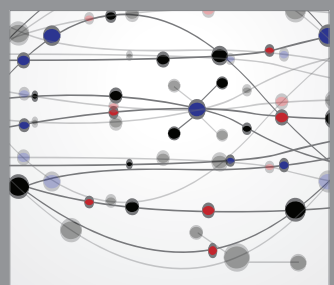

The Scientific World Journal
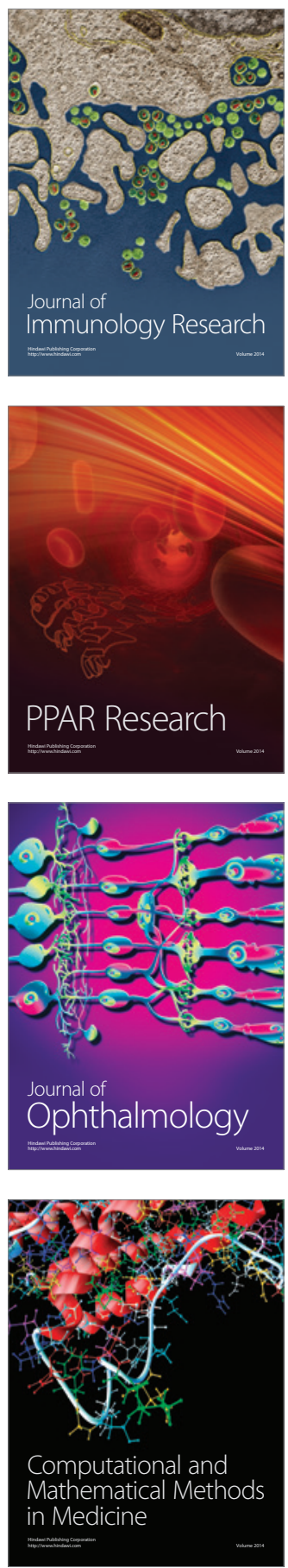

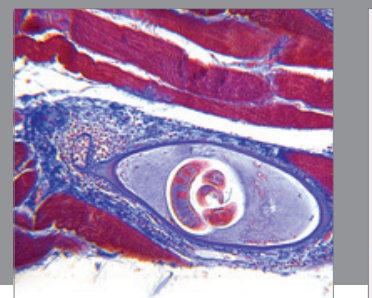

Gastroenterology

Research and Practice
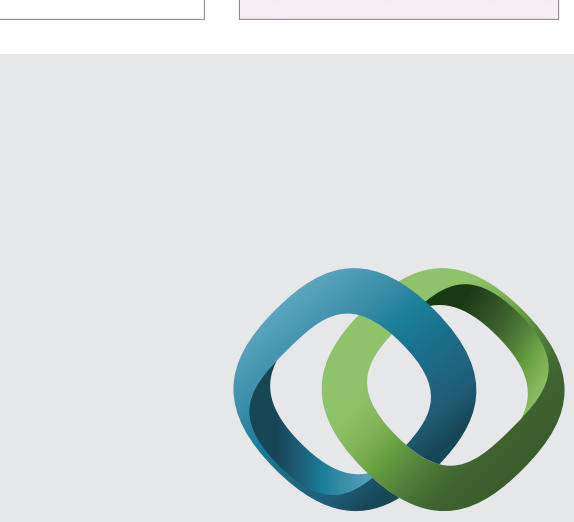

\section{Hindawi}

Submit your manuscripts at

http://www.hindawi.com
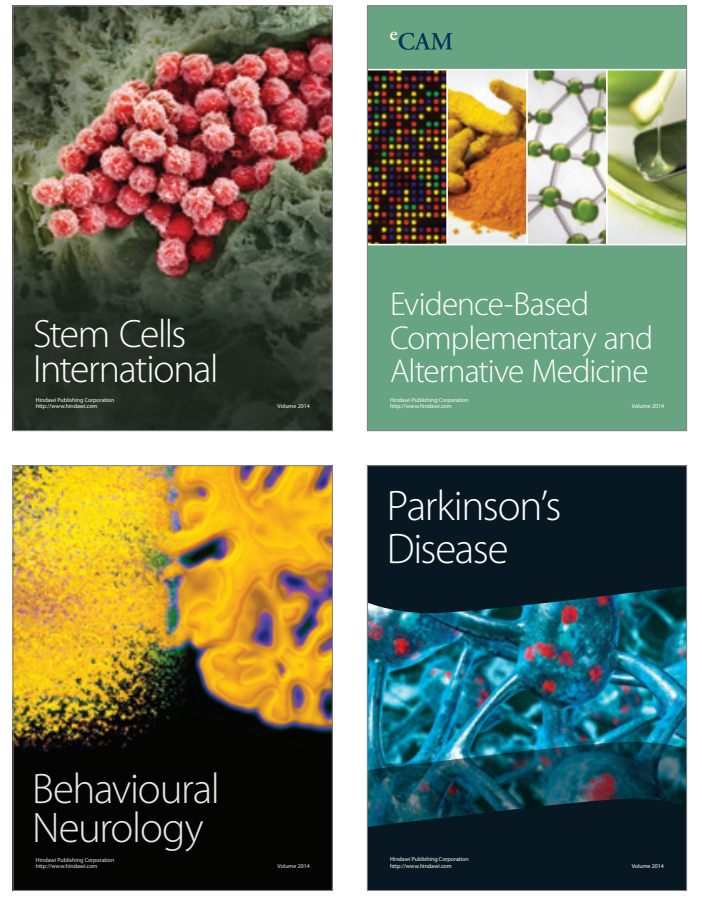
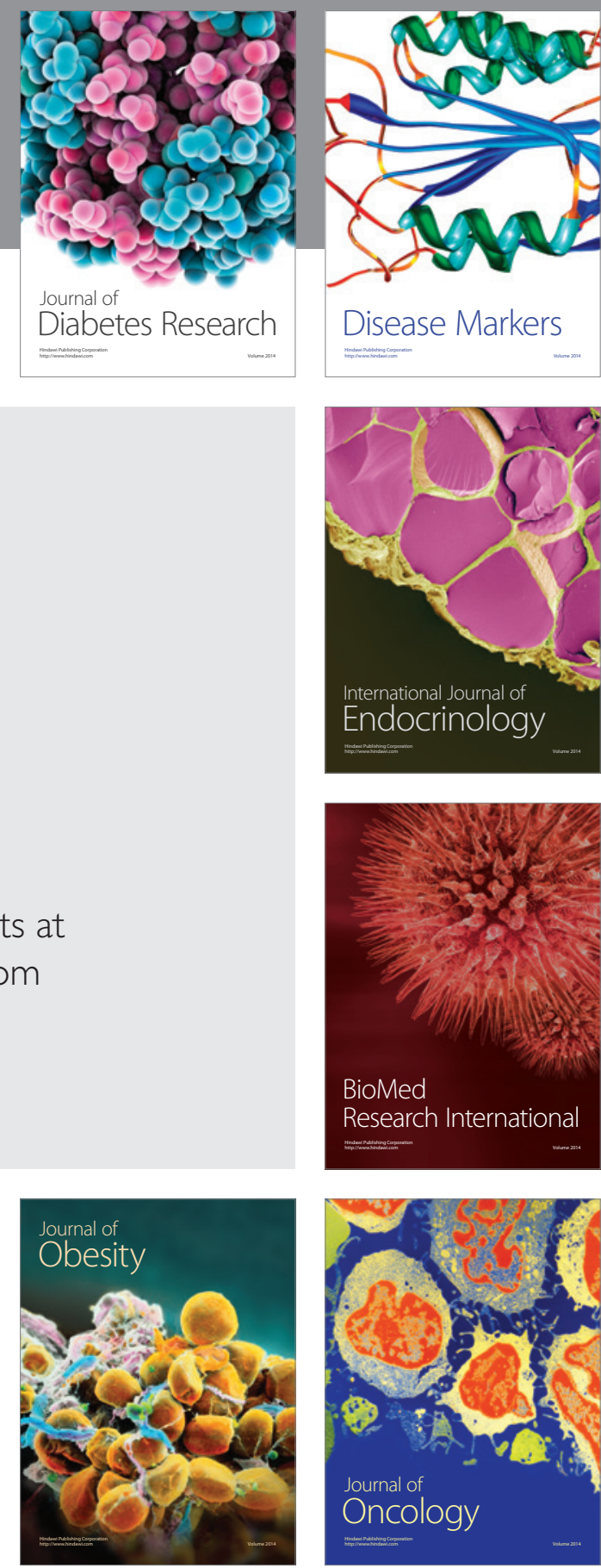

Disease Markers
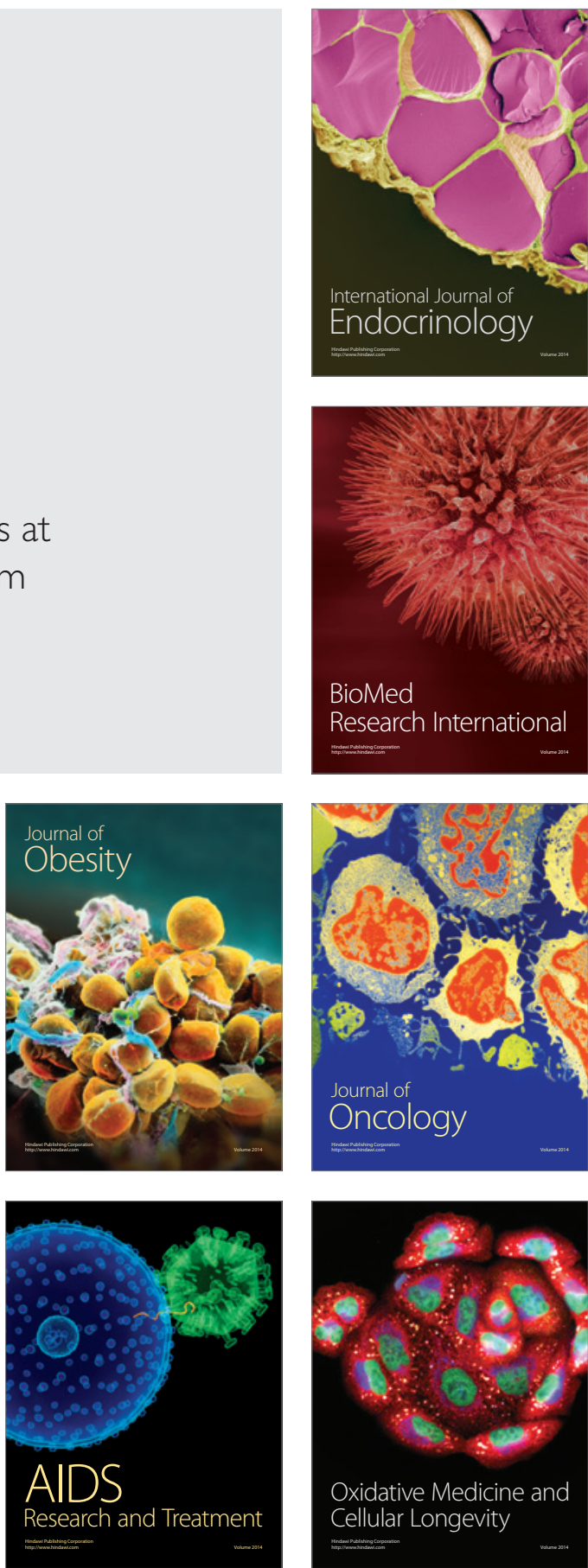